\title{
Revisiting Contemporary Judaism in Modern Israel
}

\author{
Uri Zur
}

Ariel University, Ariel, Israel

\begin{abstract}
Today's society in Israel is divided and torn on many issues, including religion, and Jewish and Israeli identity, yet occasionally, a single event emerges which combines several divisions. One such issue is the "identity crisis" also known as the question of "Who is a Jew?". This is a thorny complex problem, and one which has not yet been awarded a clear-cut constitutional solution. For example, it continues to be debated whether the religious definition should be the decisive factor, that is, should a Jew defined as an individual born to a mother who is Jewish or has been converted according to halacha, or whether Israeli identity is the more critical element and whether any individual born in or immigrated to Israel who served in the army, works and pays taxes in Israel, and identifies with the state's values should be identified as a Jew? In this paper, the author wishes to focus on equally complicated issue, although one has attracted less attention. This is the issue of halachic polarization or extremism that characterizes Judaism in modern Israel. Following a brief historical explanation, the author defines the problem at hand, and propose a solution.
\end{abstract}

Keywords: Jews, contemporary Judaism, modern Israel

\section{The Problem of Being Jewish Today}

Setting aside the issue of defining Who is a Jew? which is beyond the scope of the present discussion, leading a Jewish lifestyle requires the individual to address issues that involve many facets of life including politics, military service, education, employment, and the public sphere.

The main problem today is that modern Israeli society does not subscribe to a homogenous worldview on Judaism. Haredi (Ultra-orthodox) Jews typically form an isolated community characterized by halachic extremism. Orthodox Jewsare is also known as "Crocheted Yarmulka Wearers” (Cohn, 2009, pp. 710-716), a term used stigmatically by Haredi Jews to symbolize their supposedly more lax observance Jewish laws. While traditional Jews typically tend to "pick and choose" out of the enormous range of options available in Judaism, secular Jews consciously reject a life based on Jewish traditions or laws almost completely.

The author has no problems with the two poles at the extreme: Haredi Jews and secular Jews conduct their lives within settings that provide for all their needs, and neither group finds any need to concern itself with the other's business. The author's main concern involves Orthodox and Traditional Jews. In many cases, the members of these groups are inclined to increasing strictness and extremism on all topics related to Judaism, out of ignorance. This stands in complete contrast to the situation in the distant past, and in glaring contradiction to the example set by Beit Hillel.

Uri Zur, Ph.D., Israel Heritage Department, Ariel University. 
In breaking down the main problem of the Orthodox and Traditional Jews into more specific issues, let us first focus on the absence of individual discretion. Today's Orthodox or Traditional Jews tend to refrain from applying unbiased objective reasoning to issues of Judaism. They prefer to adopt to one specific approach or adhere to the decisions of a single public figure almost exclusively, with absolute devotion, as if following the maxim: "Appoint for thyself a teacher" (Avot 1:6) or "See like this and then sanctify" (Rosh-HaShana 20a). However, these maxims, originally designed to guide individuals with regard to the determination of halacha, are not applicable to individual lifestyle choices. Nonetheless, a large number of the religious Jews apply these maxims with fervor to their own individual lifestyle choices.

We should not be surprised that they do so. It is a very convenient attitude to take because it removes any assumption of individual responsibility. This approach allows one to rely on an authority figure who directs the entire course of life of his Orthodox or Traditional followers. This approach releases the individual from the risk of an imposing sense of guilt. The problem is that such individuals who rely on an authority in this manner also forgo the use of their own individual discretion in reasoning that might lead them to different conclusions and an entirely different course of life.

Another problem related to the main issue is that some Orthodox and Traditional Jews may also suffer from a lack of mastery and understanding of various Jewish sources texts, and not necessarily complex texts. Others who have the appropriate level of understanding of the sources prefer not to deviate from the normative Orthodox way of thinking. In other words, these individuals are not open-minded and are unwilling to consider other views, even if such views are not contradictory to Judaism. An example of their inflexibility is their opposition to the application of comparative analysis or literary criticism to Jewish source texts. The problem is that their approach leads to intellectual stagnation, has a stagnating effect on the development and dynamics of Judaism, and is inconsistent with today's reality.

Another problem is caused when individuals accept interpretations or accounts that originate in the Aggadah (third-12th century A.C.) as imperatives, or embrace various customs originating in Kabbalah (12th-13th century A.C.). Orthodox and Traditional Jews typically fail to distinguish between these two fields of Aggadah and Kabbalah — which are not truly binding — and the codex of halachic law grounded in the Talmud Bavli (third-sixth century A.C.) or Talmud Yerushalmi (third-fourth century A.C.), which is truly obligatory after having been perfected over centuries through the interpretive criticism by Mishna and Talmud scholars.

A related issue concerns the adoption of new customs, or the transformation of customs originating in the numerous sects of the Jewish Diaspora. As is well known, contemporary Orthodox Jewry in Israel is not homogeneous and comprises a broad range of sects, each of which maintains customs from various more or less recent historic periods. The problem is that some Orthodox and Traditional Jews do not tend to recognize the unique significance of the traditions of their own sect. As a result, in Israel today we see cross-sectarian adoption of customs, such as adopting prayers from other sects. In this way, the authentic customs of each sect are lost, and the ancient traditions of each sect are lost: It is doubtful that they will ever be recovered.

These issues prompt important questions. Jews in contemporary Israel who view these developments are justified in asking - What, then, is contemporary Judaism? What should the patterns of behavior of Orthodox Jews in Israel be? Is it merely a question of Orthodox and Traditional Jews? Should we all adopt this contemporary modus vivendi? 


\section{A Proposed Solution}

From an objective standpoint, the solution appears to be rather simple: What we need are persons of invigorating Jewish reasoning, persons of courage and critical thinking, able to eradicate any trace of behavior and customs that are not grounded in Jewish sources; impartial individuals who are not afraid to state the objective truth; individuals who will lead Judaism today as it was led in the past—as a tolerant lifestyle and no more; Judaism free of any financial, political, social, or status interests. Only in this way will the majority of the Jewish people today be able to become closer to Judaism, as they did in the past, when the majority of the nation followed the Jewish lifestyle advocated by Hillel.

In fact, such a solution may have already evolved among us, for example, among the Sephardic Jewry: By virtue of his extensive Torah knowledge, R. Ovadia Yossef of blessed memory, successfully unified all or most of the different Sephardic groups. One of this most decisive decisions was that halacha in Israel today should follow the rules of the great Sephardic halachist who lived in 16th century Zefat, R. Yossef Karo-for two reasons: One, it is conventional that halacha follows the most recent Poskim, and two, R. Karo lived and was active in the Land of Israel. The entire Sephardic community accepted R. Ovadia Yossef's view, on the basis of his halachic authority. R. Ovadia Yossef more of less conforms to the description in our proposal—a spiritual unbiased leader who fearlessly points to the halachic path even if it is not convenient. This is the reason that the members of the Sephardic community are his loyal followers and he is currently considered by Sephardic Jews as the generation's greatest halachic Posek, and his rules are recognized as the supreme authority.

\section{The Solution Challenged}

However, a crack occurred in which appeared to be a solution to the problem discussed above. R. Ovadia Yossef's leadership and authority were recently challenged by what was reported on October 12, 2008, in Ma'ariv, an Israeli daily newspaper, as a "Yemenite Rebellion". The story under this headline opened as follows: “Eminent Yemenite rabbis challenge R. Ovadia Yossef’s halachic leadership”.

This challenge originated in a dispute on the following halachic question: Should the candles be blessed on a holiday or not? R. Ovadia Yossef ruled that blessing the holiday candles is mandatory. One of the reasons he cited for his rule was his determination that everyone in Israel should follow R. Yossef Karo's rules (Yossef, 1986, pp. 58-59), by virtue of his eminence in halacha, because he was the last illustrious halachic Posek in Israel, and because he lived and was active in Israel. For this reason, his rulings should supersede any customs that Jews from the Diaspora brought to Israel.

In contrast, three of the most important rabbis of the Yemenite sect (R. Y. Ratzabi, R. A. Bassis, and R. P. Korah) stated that the candles should not be blessed on holidays (Ben Maimon, 1954, Shabbat 5:1), thereby implying that it is not mandatory to follow R. Yossef Karo's rulings. According to the three Yemenite rabbis, the original ancient tradition was not to bless the candles on holidays. They stated that this was the custom in Yemen, and not only should this custom not be cancelled in Israel, but it should be retained.

Moreover, these rabbis believed that by imposing R. Karo's halachic rulings, R. Ovadia Yossef was effectively eradicating all the ancient customs of the Yemenite Jews. This is a situation to which they remain strongly opposed. The dispute between R. Ovadia Yossef and the three Yemenite rabbis makes our question even more pointed for every Yemenite Jew born or raised in Israel: Should he embrace the authority of the leader R. 
Ovadia Yossef, adopt his decision, or follow the Yemenite rabbis? How can this crisis be resolved?

The following proposal is pertinent for Jews of Yemenite descent, and is also relevant for Jews who deliberate whether to follow an Orthodox or Traditional Jewish lifestyle.

\section{Resolving the Crisis}

A resolution to this crisis should be based on an understanding of the division of labor between rabbinical leaders and between Orthodox or Traditional Jewish individuals. Today's Jew should accept the authority of rabbis solely for halachic issues, and each Jew, whatever his descent or sect, Sephardic, Ashkenazi, or Yemenite, should follow the rabbi solely for the rabbi's halachic rulings. In terms of lifestyle, however, the individual Jew should assume full responsibility for his own actions. This does not imply that a rabbi cannot be consulted, but the final responsibility lies with the individual. This "relilogical" Jew is the new type of Jew that should develop in Israel today.

The relilogical Jew should study diligently and become familiar with the Jewish sources. He should maintain an open-mind and the ability to learn from other ways of reasoning, even if they are critical or oppose his own worldview, and he should learn to address them in a proper manner. He should be knowledgeable in halacha, and creative. He should address contemporary issues independently before submitting any question to the rabbi for ruling, if he decides to do so. He should have the ability to distinguish between what is halachically obligatory and what is not. He should distinguish between early and recent traditions and customs, and should be familiar with the customs of the various Jewish sects. He should strive to preserve ancient traditions and customs, and if he decides to deviate from these traditions, he should do so after an informed, reasoned decision making process based on his learning and historical knowledge. Most importantly, he should use his discretion on all matters, including matters of religion and Judaism.

\section{The Current Situation}

Earlier the author stated that a type of Jew should develop in Israel today—a "relilogical” Jew. Although the author originally thought that theory and practice were not proceeding at the same pace, the author believes that the first buds of a relilogical stance are evident in today's reality of Israel.

What does the author mean? Let the author illustrates. On December 4, 2008, morning radio host Ilana Dayan, interviewed Mr. Uri Elizur, one of the Yesha Movement leaders (Yesha is a movement advocating Jewish settlement in Judea and Samaria). Elizur was questioned on the recent Supreme Court decision to evacuate a house purchased by Jews in Hebron (also known as the "Beit Meriva" or "Beit HaShalom", depending on the perspective of the speaker) and on the violent opposition to the evacuation by Jewish youngsters against police officers and soldiers who carried out the evacuation.

Ilana Dayan posed the following question to the interviewee: "Would the youngsters in Hebron follow instructions by their rabbis or their leaders?” Dayan wished to discover whether the youngsters would cease their actions if so instructed by their leaders or rabbis.

Elizur's response was surprising. He said, “They act according to their own conscience”, implying that on certain issues there is no justification for intervention by rabbis or leaders. Rather, each and every one of the youngsters thought about the issue and decided to act according to his or her own conscience, as relilogical Jews should. 
Parenthetically, the author would like to emphasize that the new relilogical Jew, who does not rely on spiritual or political leaders but rather on his own judgment, may arrive at a decision that is right or a decision that has negative, illegal, or immoral repercussions.

\section{The Relationship Between the Jewish Individual and Modern Society in Israel}

The relationship of the individual and modern society is a complicated and painful issue. the author will not address Jewish society as a whole, but will concentrate on the relationship between the Jewish individual and modern Jewish society in Israel. Various theses on this issue exist, but here the author discusses several of the more problematic aspects of this relationship, which enfolds many issues, including whether the Jewish individual has a unique expression in modern society, and if so, what the Jewish expression in the modern society in which he exists is (Halbertal, n.d., Retrieved from http:// www.adifoundation.co.il/...\%20articles/Moshe\%20Halbertal). How should a relilogical Jew conduct himself in today's modern society? What kind of expression should be given to the positions of Jewish individuals on current religious issues? What is the attitude of the religious establishment to non-conforming individual approaches to issues pertaining to Judaism?

The general answer to all these questions is what the potential maximum degree of mutual tolerance between the individual and modern society in Israel is. In other words, the individual's ability to express himself in modern society is achievable only under mutual tolerance between the individual and modern society. This should also be the position of the relilogical Jew to modern society: He must conduct himself within the boundaries of the accepted norms of modern society in Israel, while modern society must allow him the proper and appropriate scope of freedom of action. This approach should also be applied to the worldview and judgments of relilogical Jews, and to current religious issues that emerge in various areas. The religious Jew needs unlimited freedom of thought to allow him to use his own judgments. According to this approach, the religious establishment should also exhibit tolerance, openness, and progress by encouraging freedom of thought and by supporting individuals' freedom of thought and ability to use their own judgment to express their opinions and put their decisions or conclusions into practice, even if an individual's perspective differs from the accepted norm, as long as it is within the extended boundaries that Judaism defines for individuals.

\section{Redesigning the Identity of the Relilogical Jew}

Resolution of the issue of the individual in modern society in Israel is a task imposed on various entities including the government, society, and culture, but it is also on obligation of the individual himself. The individual himself must undergo a thorough, personal transformation to reshape his identity so that he ultimately attains the level of the relilogical Jew.

The process might be long and tiring, paved with internal conflicts and crises, but it is expedient and important, because it is the means to remove the various cognitive and practical "obstacles" and "binds" in various areas, mainly in issues pertaining to Judaism which, until now, were frequently dependent on a process of questions to rabbis and their answers.

The new identity of the relilogical Jew on issues of Judaism (Meyer, 2006, pp. 127-128) should be manifest, first and foremost, in a more intense and thorough knowledge of the canonical sources of the Jewish people. The basic resources including the bible, the various traditions of oral law in halacha and Aggada, the moral literature, 
Hebrew law, and the traditions of prayer and liturgy (Schweid, 2001-2002, pp. 132-133), as well as Jewish traditions that served as the basis of education at home.

Knowledge and application of all the above is the basic foundation of reshaping the individual's identity in Israeli society, to attain the level of "relilogic" that is necessary in Israel's modern society today (Ben-Yosef, 2003, pp. 110-113).

Failure to assimilate or apply this requirement to reshape individual identity according to the standard of relilogical is currently perceived in Israeli society as a step backward in a society that is quickly progressing in a different direction, as immersion into an antiquated past, and as something obsolete that should be abandoned in entirety.

\section{The Sources of the New Relilogical Identity}

Already in the Middle Ages, Jewish philosophers expressed clear opinions on "thinking individuals", or in modern terms, "the thinking observant individual”. For example, in his volume Chovot HaLevavot, R. Bahye ben R. Yossef ibn Faqudah (1050-1120, Spain) likens those individuals who do not think independently or form their own opinions but rather are dependent on instructions of superior authorities, as blind men led by seeing men. He describes people who believe in the singularity of God based merely on tradition, without having arrived at such a conclusion on the basis of their own reasoning and understanding, as:

A group of blind men who each place their hand on their shoulder of the companion in front of them, until reaching the healthy leader ... if he ignores them and does not warn them, an obstacle will hinder them all and they will lose their way, and may fall into a pit. (ibn Faqudah, 1973, p. 49)

He continues to ask, "Must we investigate the singularity in an academic manner or not” (ibn Faqudah, 1973, p. 50). His response is the foundation for the religious dimension of the new identity, and for the relilogical dimension, the "thinking" dimension of that new identity, whose fields of reasoning and research might also encompass religious and divine matters, such as the singularity of God.

He continues:

Whoever is able to investigate this issue [the uniqueness of the divine] and everything else similar to it, through intellectual consideration ... he is obligated to investigate it to the extent of his attainment and power of understanding ... and anyone who does not investigate the issues and their truth, is act faithlessly in his Creator. (ibn Faqudah, 1973, p. 50)

This has been interpreted as follows:

Whoever has been blessed by God with common sense, the ability of discrimination, and curiosity, and has the intelligence to investigate and inquire into his environment, what is missing in it, and even into the existence and merits of God himself, owes a duty to God to make the broadest and deepest possible use of his intelligence and talents, because they were created and given to him for this purpose, and a person who does not think or contemplate as much as he can is betraying the faith of his Creator. (Cohn, 2009, p. 200)

From all this, the basis for the new "relilogical” identity can be clearly deduced. Any person endowed with mental capacities with ability for objective discernment, understanding, intellectual curiosity, and mental capability, is obliged to apply these to all of the subjects of this research. This is the obligatory aspect of the "thinking" component of the new identity. Exploration of all things religious and spiritual, and even concerning God's existence and qualities, is an affirmation of the religious component of the identity. In other words, we 
have before us the fundamental essence of the new "relilogical" man already stated in the Middle Ages, but in different wording.

The source and authority of that objective intellectual obligation stems from that same source, that is, God, who granted the individual his mental capabilities. Otherwise, for what purpose was his intelligence granted to him? If God did not wish for man to think or make use of his mental faculties, he would have limited him from the onset, from creation, just as He did not want Man to live forever and therefore limited his lifespan and decreed death for Man at the end of his days (Gen. 3:19).

In light of all the aforesaid, one who does not utilize his abilities and faculties granted him by God but instead relies upon the opinions of others who do his thinking for him or in his stead, without bothering to learn and think for himself in order to form or express his own opinion, is likened to a blind man and a blind man is comparable to a dead man (Nedarim 64b).

The Jewish philosopher, R. Joseph Albo (Spain, 1380-444) wrote in a similar manner in his book Sefer HaIqarim (1951) as follows:

And I was obligated to write all this as I saw that there were frivolous people ... lacking knowledge or understanding. From this, derives the permission for every wise person to inquire into the principles of religion and elucidate the verses in a manner that concurs with the truth according to his opinion. And even though he does believe in some of the statements set down by early Masters_-principles such as the coming of the messiah, renewal of the world, and so forth, but they are not fundamentals ... he is not to be considered, Heaven forbid, as denying the Torah or its fundamentals. (pp. 52-53)

From Albo's statements the basis for a new identity of the "relilogical" man can also be deduced. He "permits" any "wise person" (that is to say, man's "thinking” aspect) "to inquire into the principles of the religion” in all religious matters as research objectives or researchable subjects. This is man’s “religious” aspect of the new identity, which is permitted to investigate all issues of the religion.

That is to say, if a person "thinks" upon a certain "religious topic" (e.g., the coming of the messiah, which is the example Albo uses) that it is not one of the principles of the faith (in contrast to the opinion of Rambam, who believes that it is one of the Thirteen Principles of the Faith (Ben Maimon, 1954, Sanhedrin 10:1), he is not to be considered an apostate).

In light of all that was previously said, from this one can also deduce the basis for the perception of the new "relilogical” identity.

\section{Are There Limits to the Topics for Contemplation by the "Relilogical Man"?}

In principle, any subject that the Torah has not forbidden for reflection is permitted for thinking and mediating, even if such contemplation entails evil thoughts. We learn this from the Torah's words, You shall not hate your brother in your heart (Lev. 19:17). The Torah forbids one to silently hate his brethren, that is to say, to think evil thoughts about your neighbor. From this we conclude that thinking evil thoughts is not a transgression of the Law and is certainly not subject to punishment, so long as the Torah did not forbid it (nonetheless, evil thoughts indicate that such a person should be more virtuous, and study the ethical literature to correct his ways).

The Academy of Hillel also thought so in their difference of opinion with Academy of Shammai concerning the verse from the Torah, "to see whether he has put his hand to his neighbor's goods. For every word of trespass" (Ex. 22:7-8). The Academy of Shammai explains: “This is to intimate liability for [expressed] intention as for 
actual deed". The Academy of Hillel explains: "He is not responsible unless he actually misappropriates it" (Kiddushin 42b). Their disagreement concerns the boundaries of topics of contemplation. According to Bet Shammai, an evil thought is just like an evil act and is forbidden. According to Bet Hillel, an evil thought is not an evil act until a person actually performs some action.

The following discussion between the Sages of the Tannaitic period found in the Babylonian Talmud concerning the drafting of the final eight verses of the Torah (Deut. 34:5-12), takes this issue of defining the limits of absolute freedom of topics of contemplation.

The Master has said: Joshua wrote the book which bears his name and the last eight verses of the Pentateuch. This statement is in agreement with the authority who says that eight verses in the Torah were written by Joshua, as it has been taught: [It is written], So Moses the servant of the Lord died there [Deut. 34:5]. Now is it possible that Moses being dead could have written the words, “Moses died there?” The truth is, however, that up to this point Moses wrote, from this point Joshua wrote. This is the opinion of R. Judah, or, according to others, of R. Nehemiah. Said R. Simeon to him: Can [we imagine the] scroll of the Law being short of one word, and is it not written, Take this book of the Law? [Deut. 31:26] No; what we must say is that up to this point the Holy One, blessed be He, dictated and Moses repeated and wrote, and from this point God dictated and Moses wrote with tears (Bava Bathra 15a).

The disagreement between R. Judah and R. Simeon illustrates the point until which one can stretch the limits of the topics of contemplation on religious matters. According to R. Judah, there almost no limits at all. R. Judah entirely negates the possibility that the final eight verses were written by Moses, based on the following rationale that he presents: How can one explain the fact that he wrote that he died although he had already died?! Since that is impossible, R. Judah (Bava Bathra 15a) (2nd century A.C.) concludes that Moses did not write the final eight verses of the Torah but it was Joshua who completed the Torah's final eight verses describing the death of Moses. At this point of the Talmudic debate it does not record anyone from among the Sages vehemently protesting against R. Judah's statement. None of the Sages admonished R. Judah for being a denier of the Torah; there were no provocations, sanctions, or violence of any kind. On the contrary, the discussion represents a legitimate difference of opinion between those Sages, with each one holding a different opinion concerning those final eight verses of the Torah.

Indeed, further along the discussion, an opinion opposing R. Judah's opinion, is presented. According to R. Simeon (Bava Bathra 15a) (2nd century A.C.), his opponent's point of view, the entire Torah, from God, was written by Moses, including the final eight verses. He is unwilling to accept the fact that the entire Torah was not written by Moses from God. On the other hand, he overcomes the impossible facts by developing his own description of the process: In this way he distinguishes between Moses' situation when writing the Torah ("Moses repeated and wrote") and his situation when he is requested by the Holy One Blessed be He to write about his death ("Moses wrote with tears").

This tolerance for differences of opinions between the Sages without admonishing R. Judah for his unique opinion that so significantly differs from conventional thinking on such a sensitive topic as Moses' writing of the Torah dictated to him by God, symbolizes the extent of the permitted limits of thought on any religious subject, that already existed in the Tannaitic period.

Another example of stretching the limits of contemplation linked to the text of the Torah can be found in the 
Babylonian Talmud where it states: "One taught: There was an assiduous student at Jamnia [f. 6: "Or Jabneh"] who by a hundred and fifty reasons proved that a [dead] creeping thing was clean” (Eruvin 13b).

The Sages were puzzled (Tossafot, Eruvin 13b, s.v: “Sh’yodea”): "It is puzzling, what was the sharp mindedness it took to render the reptile pure when the Torah has already rendered impure”. That is to say, what was the sharp mindedness, what was the wisdom, in striving to render a reptile pure using 155 excuses when the Torah (force majeure) had already explicitly stated that the reptile was impure? Was that senior disciple disputing the Torah not a single one of Yavne's Sages bothered even to remark on that to him?

This passage may be viewed as further evidence from the Tannaitic times about the limits of contemplation, including even subject that clearly appear in the Torah, which were ostensibly clear and should not have incited any differences of opinions, yet it is possible to stretch the limit of contemplation even if such contemplation is unconventional, such as the opinions of the above "assiduous learner".

However, one must note that in later times, such as for example, in Rambam' time, the topics for thought for the contemplative person were already limited, at least with regard to religious subjects, due to the fear of people's limited capabilities. And so Rambam determines:

Any thought that causes a person to uproot any one of the principles of the Torah, we are warned not to raise, and not to cogitate upon it, or follow the dictates of our hearts, because people's minds are limited, and not all minds can perfectly encompass the truth, and thus enters into apostasy. (Ben Maimon, 1954, Avodah Zara 2:4)

Rambam presents examples of prohibited thoughts, including thoughts about the Creator's unity ("perhaps he is or perhaps he is not”), or about prophecy ("perhaps it is true or perhaps it is not"), or the Torah ("perhaps it is from Heaven or perhaps it is not”) (Ben Maimon, 1954, Avodah Zara 2:5). However, as stated before, others including Albo in Sefer HaIqarim, did not accept Rambam’s opinion on this point.

\section{Illegitimate Relilogical Decisions}

In the relilogical person's decision-making system, it is not legitimate to oppose the commandments of the Written or Oral Torah, or the rulings of previous sages. This is an accepted principle and so there is no reason to expand on this topic. However, there are other topics where the "relilogical" individual may make illegitimate decisions, for example, decisions on all the universal issues. Let us focus on ethics, for example. There is universal, elementary ethics which is a natural imperative, and one that is accepted by the majority of intelligent people everywhere and in all times (Shafran, 1969, p. 215). Any decision by the "relilogical” person that goes against universal ethics would be an illegitimate one. The same holds for universal justice, virtuous behavior, and so forth. It should be emphasized that all these tenets preceded the Torah, which underscores their universality as well their mandatory nature. Universal ethics and universal justice are known by the well-known phrase, "the Seven Noahide Laws" (Sanhedrin 56a) which predate the Torah. That good manners predate the Torah is concluded the Mishnah: "Where is no good manners there is no Torah" (Avot 3:17), which means that good manners existed before the Torah, and even existed in the prolonged period of the twenty-six generations before the Torah was given to Israel (VaYiqrah Rabbah, Tzav 9:3, p. 92, Mirkin Ed.).

Other issues are mandated by common sense. For example, if one borrows money or an object from a friend, he is obliged to return it to him. There are other topics that naturally obligate the individual, such as, for example, honoring one's father and mother; the duty would exist even if it was not one of the Torah's commandments. A 
person naturally respects his parents. This is also true for other topics linked to mercy or compassion that are natural for a person to perform: Even animals act in that manner, such as animal mothers who have compassion for their offspring. Therefore, any decision against such principles would be considered illegitimate.

\section{The Essence of the Argument Underlying the "Relilogical" Identity}

Everybody is required to study the Torah since that is the instruction handed down to Joshua, Moses' successor:

This Book of the Torah shall not depart from your mouth; but you shall meditate on it day and night, that you may observe to do according to all that is written on it; for then you shall make your way prosperous, and then you shall have good success. (Jos. 1:8)

The object of studying the Torah is for learning's sake as a commandment that must be observed and fulfilled, as stated in that verse. As a person studies extensively, and advances in his study, he then "shall have good success", or literally, becomes wise. He can then attain a higher level of skills in instruction and teaching others. And naturally, he can make decisions on various religious matters by himself and for himself.

Here is a simple example: A rabbi can decide on religious matters independently. He is not required to go to another rabbi to consult with him on the topic of his deliberation, although he certainly may do so if he wishes. His individual capacity to make a decision on a specific topic stems from his great store of knowledge. Therefore, we can conclude that this also applies to the "relilogical" man who is an intellectual and studies extensively, and is knowledgeable on religious and Judaic matters. Similarly to the rabbi, he, too, can make a decision. He is likewise not obliged to consult with a rabbi if he does not feel any need to do so.

This is a basic insight that Ezra the Scribe quickly developed as early as the middle of the fifth century B.C., after he came to the Land of Israel from Babylon and observed that the Israelites in Israel were negligent in observing the commandments (Neh. 1:7; Ez. 9:2-3), they failed to observe the commandments relating to Temple service (Ez. 4:24), and after the exile of "the carpenters and metal workers" (Kings 2, 24:14).

Ezra the Scribe hastened to rectify these digressions by transferring the authority of teaching from the pedigreed theocratic elite (the priests) and from the seers (the prophets), who had the authority to demand obedience, to the knowledgeable people (the wise men) who studied and knew the Torah. And so it is written: “ ... and the Levites, helped the people to understand the Torah ... So they read in the book in the Torah of God clearly, and gave the interpretation, so that they understood the reading” (Neh. 8:7-8). The Levites who know the Torah are those who read and teach the Torah, based on their knowledge of the Torah and their ability to interpret and explain the Torah to the people in an intelligent manner so that the people could understand the words of the Torah.

Although Ezra learned from his rabbis, he was an autodidact. And so it is written about him: "For Ezra had set his heart to study the Torah of the Lord, and to do it, and to teach in Israel his statutes and judgments” (Ez. 7:10).

Credentials or qualifications are insufficient because learning and knowledge are what conferred upon a person the title of a learned Sage. This was the case until the last student of Hillel the Elder: From Rabban Johanan ben Zakkai (Sukkah 28a), all the renown sages were called by their personal names, such as Shimeon the Just (Avot 1:2) Shemaia and Avtalion (Avot 1:10) without noting any rabbinical title whatsoever ("Rabi is greater than Rav, Raban is greater than Rabi, and his name alone is greater than Raban”) (Halevi, 1970, p. 9). 
At some stage it was even determined that a sage had precedence over a prophet. This is based upon the verse "that we may gain a heart of wisdom" [lit., a prophet is one who has a heart of wisdom] (Ps. 90:12), which implies that knowledge gained through learning and study is more important than prophecy. In practice, since Ezra, there were no prophets, and the period of the Sages began and has lasted until our own age, which is based on the importance of study that confers knowledge. This was also what the Sages had determined: "Study is greater. For it leads to action” (Kiddushin 40b). If somebody learns something he will probably put it into practice, and thereby gain not only study but benefit from the action as well. A person who merely performs the act, does not profit from the study of the matter.

All the aforesaid constitutes the foundation of "relilogical" identity that should materialize in our times. With such a higher level of the "Relilogical" man's stature, comes the obligation to utilize his abilities in inquiring into all matters, even those concerning the divine, as determined by R. Joseph Albo in Sefer Ha'iqarim, which we mentioned before.

\section{Additional Examples of the "Relilogical" Practical Method}

Examples of practical thinking can be found in the Babylonian Talmud from that period. From it we can also infer a practical method for the "relilogical" man that applies to our own period.

One of the accepted conventions of the Talmud's rules is that no sage from the Amoraic period (3rd-6th century A.C.) should contest the sages from the previous Tannaitic period. If such a situation nonetheless arises, the Amoraic sage is permitted to disagree only of he presents support for his opinion by referring to earlier sources or earlier sages from the Tannaitic period who appear to agree with his opinion. Such a situation is described in the Talmud as “Tannai Hie” (Sirilio, 1972, p. 147) or “Tania Kevateih DePloni” (Sirilio, 1972, p. 145). Borrowing from the field of logic, such circumstances are known as argumentum ad verecundiam, or in Hebrew (literally) "hanging from tall trees".

The analogy to this situation in our times is manifest in the "relilogical” man's practical conduct, which are also based on an appeal to authority. One option is to pose a "question" to a rabbi, which is the easiest method that absolves him from learning the material or taking responsibility for his personal decisions. The second option is preferable, since it obliges one to thoroughly study the subject and assume personal responsibility for its implications. That is to say, in order to address any problem, one needs to thoroughly study the material on the topic that can be found in all the relevant and reliable sources, which will ultimately expand the learner's knowledge base. In this manner, the inquisitive intellectual can independently make an appropriate decision on the topic of his interest, without needing or relying on the decisions of others, and assuming responsibility for the consequences of his decision. From his perspective, those reliable sources constitute "the authority". As noted above, one example is the difference of opinion concerning the blessing over the holiday candles, between the three Yemenite rabbis and R. OvadiaYossef, in their reliance upon tradition and Rambam rulings.

Another example of "relilogical" practice concerns topical questions on religion that emerge in a certain place, such as the construction of a synagogue in the heart of a residential neighborhood. To resolve the problem, two different and opposing points of view are presented. The first relied upon "putting a question to the rabbi" who determined that one cannot oppose the construction of a synagogue in the heart of a residential neighborhood. The second position, representing the approach of the "relilogical" man, concluded, after having studied and 
examined the subject and the sources, that the community should be compelled to accept the construction of a synagogue only if no other synagogue exists there (Ben Maimon, 1954, Laws of prayer 11:1). The implication of this was that if other synagogues already exist in the area then a [another] synagogue should not to be built within the heart of a residential neighborhood.

The "relilogical" man's practical method can also rely upon a logical method or normative supposition since they too were acceptable among the Sages and can also be applied today. A logical method that was already used by the Sages in decision making was the a fortiori rule. One classic example from the Sages is based on the story of Hillel and B'nei Beterah. They did not know if bringing the Paschal sacrifice on the Sabbath overrides Sabbath prohibitions or not. Hillel answered them that the Paschal sacrifice did defer the Sabbath, and he based his statement on the learning method of analogy (G'zerah Shavah). This method requires knowledge of the theoretical study material—just as Hillel had learned from his teachers who were the great authorities in their generation, and application of this logical form of argument based on a fortiori (Kal VaChomer) (Peschim 66a).

We found an example of normative supposition about citations from the Sages in a statement by R. Johanan (3rd century A.C) who said: "If the Torah had not been given we could have learnt modesty from a cat, honesty [f.6: "Lit., '(objection to) robbery”'] from the ant, chastity [f.7: "Lit., 'forbidden intercourse’”] from the dove, and good manners from the cock” (Eruvin 100b).

In light of all of the aforesaid, it is true today as it was in the past: A person may reach decisions on religious matters relying upon the logical method of a fortiori, on the condition that there are no contradicting statements, or decisions may be based on normative assumptions that meet a fixed logical standard and do not contradict statements that were discussed in the past and on which obligatory conclusions were reached. An example that is as relevant today as it was in the past is all the matters related to the issue of whether life-saving defers, or overrides, the Sabbath.

\section{Conclusions}

This paper opened with a short description of the problem of Israeli society, and its implications in terms of the Halachic radicalization that Judaism is currently experiencing, in comparison with the past, focusing mainly on the religious and traditional sector, which accounts a considerable portion of Israeli society. The source of the problems in this sector is the loss of individual discretion in the religious and traditional sector; the absence of learning and the lack of learning ability; failure to assume personal responsibility, and an unwillingness to bear the practical consequences of such responsibility. One solution proposed for all these problems was to promote the public to call on an objective leader who would outline a proper course of action in Judaism, thereby resolving or avoiding some of the problems.

Apparently, a practical opportunity for this option now exists, although this solution remains academic because of differences of opinion and lack of agreement for the path outlined on the aforementioned issue of holiday candle lighting, which illustrates the danger in a lack of consensus on the practice of Judaism. A second opportunity that was created as a result, is based on a division between rabbinical authorities whose task is to teach Jewish law (halacha), and the "relilogical" individual who studies, is calculated, responsible, and is able to reach decisions independently, even decisions on religious matters, based on his own knowledge.

Thus two distinct types of religious people developed: The first, and perhaps as in the past, appeals to 
rabbinical authority on all matters, including matters that do not involve halachic instruction; The second, the studious one, reasoned, responsible, who is capable of making his own decisions even on religious matters in light of his knowledge. This is whom we called the "relilogical Jew". He appeals to rabbinical authority but only on issues that he initiates and raises which are related to halachic rulings (Ben-Rafael, 2009, pp. 430-431).

The buds of this second type have already begun to sprout and exist in certain places in Israel. The question is, will such a trend continue to develop or not? Will there be sufficient tolerance between the solitary individual and the religious framework in Israel or will this phenomenon be terminated prematurely? Time will tell, since it is dependent on restructuring of "relilogical" identity and on the socio-religious framework that he confronts. The second type of religious individual is not created ex nihilo. It is a legitimate concept: The Sages have already referred to this type, as have Jewish philosophers from various periods, who have encouraged the perception of man "thinking" for himself.

It is impossible to prevent differences of opinion and deliberations on this concept, and on topic of whether we should define limits or not, and if we do, what limits should be defined. Still, all this is not new. Differences of opinion were common even among the Sages, as well as among their commentator, on the limits of freedom of thought. Should it also include matters of God or does this constitute evil thoughts or denial of the Torah? There are related deliberations, such as whether there are decisions that are illegitimate decisions, and if so, on what matters?

Deliberations should not undermine the essence of the argument that speaks of the need for such a new identity today. This argument remains firm and indispensable. From a practical perspective, this concept is already in practice among a small number of religious people in Israel, who apply "relilogical” practices to various religious matters.

\section{References}

Albo, Y. (1951). Sefer HaIqarim. Tel Aviv: Mossad HaRav Kook.

Ben Maimon, M. (1954). HaYad HaHazakah (Maimonides' deuteronomy). Jerusalem: El HaMekoroth Press.

Ben-Rafael, E. (2009). Jewishness in a Multicultural Era. In E. Ben-Rafael, A. Bareli, M. Chazan, \& O. Shiff (Eds.), The Jewish people today: Ingathering and dispersion essays in honor of Yosef Gorny (pp. 430-431). Jerusalem: Yad Izhak Ben-Zvi Press.

Ben-Yosef, S. (2003). Restoring Jewish communalism. Akdamot, 13, 103-130.

Cohn, H. (2009). Law and religion. Or Yehuda: Kinneret, Zmora-Bitan, Dvir Publishing House Ltd..

Halbertal, M. (n.d.). Otonomya VeSamchut BaMachshavah HaYehudit HaModernit (Autonomy and Authority in Modern Jewish Thought). Retrieved from http://www.adifoundation.co.il/...\%20articles/Moshe\%20Halbertal

Halevi, Y. (1970). Halicot Olam. Tel Aviv: Shilo Press.

ibn Faquda, B. (1973). Chovot HaLevavot (The duty of hearts). Jerusalem: Akiva Yossef Press.

Meyer, M. A. (2006). Judaism within modernity essays on Judaism history and religion. Tel Aviv: Am Oved Publishing Ltd..

Schweid, E. (2001-2002). Tarbut, Kehilah VeHemshechechut HaAm HaHayehudi Bezmanenu (Culture, community and the continuity of Jewish people Nowadays). In S. D. Pergola, \& A. Yovel (Eds.), The president's study on world Jewish affairs (pp. 132-133). Jerusalem: HaSifria HaTziyonit Publishing House of the World Zionist Organization.

Shafran, A. (1969). Mussar VeChevrah BaIdan HaModerni (Morality and society in modern era). In M. Zohori, \& A. Tartakover (Eds.), Hagut Ivrit Be'Eyropa (Hebrew cogitation in Europe) (p. 215). Tel Aviv: Yavneh Publishing House.

Sirilio, S. (1972). Klalei Shmuel (Shmuel's rules). Jerusalem: Divrei Sofrim Press.

Yossef, O. (1986). Yabi ‘a Omer responsa (Uttereth speech rsponsa) (Vol. II). Jerusalem: Ovadiah Yossef Press. 